\title{
Article \\ Artisanal Products and Land-Use Land-Cover Change in Indigenous Communities: The Case of Mezcal Production in Oaxaca, Mexico
}

\author{
María G. Lira ${ }^{1, *(\mathbb{D})}$, Iain J. Davidson-Hunt ${ }^{1}(\mathbb{D})$ and James P. Robson ${ }^{2} \mathbb{D}$ \\ 1 Natural Resources Institute, University of Manitoba, Winnipeg, MB R3T 2M6, Canada; \\ iain.davidson-hunt@umanitoba.ca \\ 2 School of Environment and Sustainability, University of Saskatchewan, Saskatoon, SK S7N 5C8, Canada; \\ james.robson@usask.ca \\ * Correspondence: marialiraledesma@gmail.com
}

check for updates

Citation: Lira, M.G.; Davidson-Hunt, I.J.; Robson, J.P. Artisanal Products and Land-Use Land-Cover Change in Indigenous Communities: The Case of Mezcal Production in Oaxaca, Mexico. Land 2022, 11, 387. https:// doi.org/10.3390/land11030387

Academic Editor: Troy Sternberg

Received: 2 February 2022

Accepted: 28 February 2022

Published: 5 March 2022

Publisher's Note: MDPI stays neutral with regard to jurisdictional claims in published maps and institutional affiliations.

Copyright: (C) 2022 by the authors. Licensee MDPI, Basel, Switzerland. This article is an open access article distributed under the terms and conditions of the Creative Commons Attribution (CC BY) license (https:// creativecommons.org/licenses/by/ $4.0 /)$.

\begin{abstract}
Artisanal products are considered an alternative to industrial production; however, upon entering global commodity markets, pressures are placed on the territories and customary governance of producer communities. Through the lenses of land system science and telecouplings, this paper examines the links connecting global markets and artisanal products, using the case of mezcal production in an Indigenous community in Oaxaca, Mexico, and the resulting impacts to LULC (landuse and land-cover) dynamics and associated governance. Data were collected through document review, semi-structured interviews, and LULC analysis comparing the years 1993, 2001, 2013, and 2019. Agave crops expanded from 6 to 14\% during 1993-2001, stabilized through 2001-2013, and expanded from 14 to $22 \%$ during 2013-2019. Market dynamics played a crucial role in the resultant LULC changes, with the biggest impact on tropical dry forest (TDF). The LULC results were coupled with tequila markets during the first two periods, while the third period was linked to new mezcal markets. Our research shows how artisanal production can drive LULC changes. However, customary governance institutions can mediate the relationship between producers and markets to support more sustainable management of territorial resources, including TDF as an ecologically important but locally undervalued forest type.
\end{abstract}

Keywords: Indigenous communities; Oaxaca; global markets; mezcal; agave; land-use land-cover

\section{Introduction}

Land system science is an evolving field that has produced key methodological advances and numerous empirical observations related to LULC (land-use and land-cover) dynamics and patterns [1-3]. It has made use of satellite imagery, land change modeling tools, and research on LULC change drivers to improve our understanding of land management and associated impacts on earth systems, land transition dynamics, and scenarios for future changes [4]. Advances in earth observation techniques and information technologies have enabled LULC changes to be monitored at multiple spatial and temporal scales $[5,6]$.

Gradually, the field has evolved to address not only localized land change processes but globally connected land systems impacted by rural economic changes, urbanization processes, and global demand [7]. This has included a focus on the systems, flows, causes, and effects linked to the global trade of agricultural commodities [8] and the idea of "telecouplings" [9] or the processes that connect distant places through the consumption of land-based trade commodities [10]. Recent work has brought to light the importance of understanding how global supply chains link consumption in one place to changes in LULC in another [11]. While early work on LULC change tended to focus on quantitative approaches to document change at particular sites, recent work has looked to integrate 
social and cultural dimensions and enhance understanding of consumption-driven LULC outcomes in coupled human-environment systems [12].

While distant linkages connect value-chain actors located in different parts of the world, they pose challenges to community-level land governance [13-15]. For example, industrial crops that form part of global value chains have become important drivers of LULC processes [16-20]. Remotely sensed data show how intensive mechanized processes to produce palm oil in Southeast Asia [17,21,22] or soybean in South America [22-24] have driven deforestation, biodiversity loss, and conflicts in traditional territories [25]. Understanding how land tenure, land governance, and values may lead to different outcomes from telecoupling is one important way that land systems approaches make critical examinations of sustainability $[11,12,26]$. Recent work has built on the perspectives of actors in global value chains-from consumers to traders, certifiers, and producers-to develop programs that support the sustainable transformation of such chains [27].

However, while work on global commodities such as soybean and palm oil has been notable [17,21-24], the incorporation of artisanal products [28] into global markets has been far less of a focus in land system science. These products, as is the case with "Traditional foods" [29,30], "regional specialty products" [31-33], "special quality" products [34,35], and "typical products" [36], are sourced predominantly from rural and indigenous communities, and have emerged (in global markets) as a response to the dominant agro-industrial paradigm of food production. They offer an alternative to the intensified, standardized, and nutritionally engineered nature of functional foods [37]. Most are produced within smallscale systems and often associated with inherited traditional production techniques used to process local raw materials [29,38,39]. Their value lies in symbolism around rurality [29,40], craftsmanship and (sense of) quality [41], and production and exchange values that offer alternatives to industrial schemes [41,42]. The commoditization of such products targets consumers who hold social and/or environmental concerns and want their purchases to contribute to the sustainability of producing communities [43-45]. Subsequently, product branding is often based on place of production and ideals of authenticity $[46,47]$ and often supported by place-based policies that promote the revalorization of local resources, the revitalization of local economies, and sustainable rural development [45].

Yet commoditization inevitably requires local producers to interact with global markets-markets that demand a level of production (supply) that may be incompatible with embedded traditional and craft systems. When incorporated into the dynamics of global markets, increased demand and rising prices may change the logic of production, with an impact on producer communities and their local commons [48-52]. In such cases, while sustainability principles may be promoted and even become a part of product branding, production itself may not be environmentally and/or socially sustainable [53]. When it comes to industrially produced agricultural commodities, the effects of commodity markets on land-use dynamics in tropical regions are well discussed in the literature [16-20]. For artisanal products, while the cultural, social, economic, and environmental sustainability dimensions have been evaluated [54-57], the LULC dynamics linked to associated production processes have rarely been addressed.

This is where the study presented here makes its contribution. We use the case of mezcal - a craft spirit produced in Mexico from multiple varieties of the agave plant, whose value chain began with inter-community trade and then stretched to include national and global value chains - to illustrate the telecoupling of artisanal production to global markets, the resultant LULC change, and how this creates intracommunity tensions that require mediation through communal values and institutions. We make use of remote sensing techniques to analyze the impact that growing demand for mezcal is having on LULC dynamics in producer communities and qualitative methods to understand how on-the-ground events shape change in communally owned and managed landscapes. We next describe our study region and site, detail the recent history of mezcal production, and explain our research approach and methods. We then present the results of our LULC analysis, document review, and interviews in the field. Our discussion builds on these 
empirical findings to offer a critical reflection around the LULC dynamics that are tied to emergent markets for mezcal as an artisanal product. We end with a brief conclusion.

\section{Study Region, Study Site, Materials, and Methods}

\subsection{Study Region and Mezcal Sector}

Oaxaca is a state in southern Mexico surrounded by the states of Guerrero (West), Puebla (Northwest), Veracruz (Northeast), and Chiapas (East). An estimated 90\% of Mexico's mezcal is produced in Oaxaca [58] with most of that production concentrated in the so-called "mezcal region" that covers the districts of Yautepec, Santiago Matatlán, Tlacolula, Miahuatlán, Ejutla, Ocotlán, Solá de Vega, and Zimatlán [61]. The "mezcal region" was defined in the official DO (Denomination of Origin) declaration in 1994 [59] and seen as a way to boost the agave and mezcal industry, improve the livelihoods of producers, and increase competitiveness of mezcal in global markets [60]. Most of this mezcal comes from cultivated Agave espadín (A. angustifolia with a life cycle of 4 to 8 years) [58], with some produced with wild agave species, such as Tepeztate (A. marmorata) (up to 25 years to maturation), Jabali (A. convalis) (up to 12 years for maturation), Arroqueño (A. americano) (up to 25 years for maturation), and Cuish (A. karwinskii) (12-15 years to maturation). The agave species harvested and production process in use vary according to place, the raw materials (inputs) available locally, and what traditional production techniques are favored. However, in general, the process involves 5 key steps: agave planting and harvesting; the baking of agave pineapples; the crushing of baked agave; fermentation; and distillation. Traditionally organized as a family-scale activity, production uses locally designed and made tools such as in-ground ovens, mallets, tahonas, clay-pot distillers, and wood fermentation containers.

Mezcal was long perceived as a drink consumed in traditional production areas. However, during the last two decades, its wider popularity has increased, to the point where it is currently consumed by national and international urban elites [62]. As a result, there is a growing demand not only for mezcal but also for agave as the main raw material used in its production. Over $47 \%$ of agave cultivation in Oaxaca's mezcal region is found in Tlacolula district, in Oaxaca's Central Valleys region, where TDF (tropical dry forest) is dominant [63]. More than half of the world's TDFs are in the neotropical Americas [64], with 38\% of these forests in Mexico [65], where they harbor 31\% of the country's endemic vertebrate terrestrial species [66] and 50\% of its endemic vascular plant species [67]. TDF is home to species considered highly adaptable to low and seasonal water availability, an important attribute given future scenarios of climate change [68]. TDF also provides important ecosystem services, from climate regulation to the maintenance of soil fertility and as habitat for pollinators for local agricultural crops [68]. These forests are also a source of food, medicine, timber, and fuel for local communities. In recent decades, researchers have identified multiple threats to TDF [69], with agriculture, livestock farming, and human infrastructure the most prevalent $[70,71]$.

\subsection{Study Site}

The community of San Juan del Río (hereafter referred to as "San Juan") is in the Central Valleys region of Oaxaca, southern Mexico (Figure 1). The community's territory covers 6948 hectares and is home to 1372 inhabitants [72], of whom 90\% are Indigenous Zapotec speakers [72]. Terrain is hilly (from 1000 to 2600 m.a.s.l.) and covered by TDF, with smaller areas of mixed pine-oak forest in the more elevated eastern zone [73]. The local climate is hot, semi-arid, and sub-humid, with most rain falling in the summer months. Due to the dry climate and hilly topography, San Juan's lands are mostly unsuitable for traditional rain-fed agriculture but appropriate for agave that is well adapted to such conditions. In the most fertile lands, adjacent to the river that runs through the community, people plant corn (often in between rows of agave). 


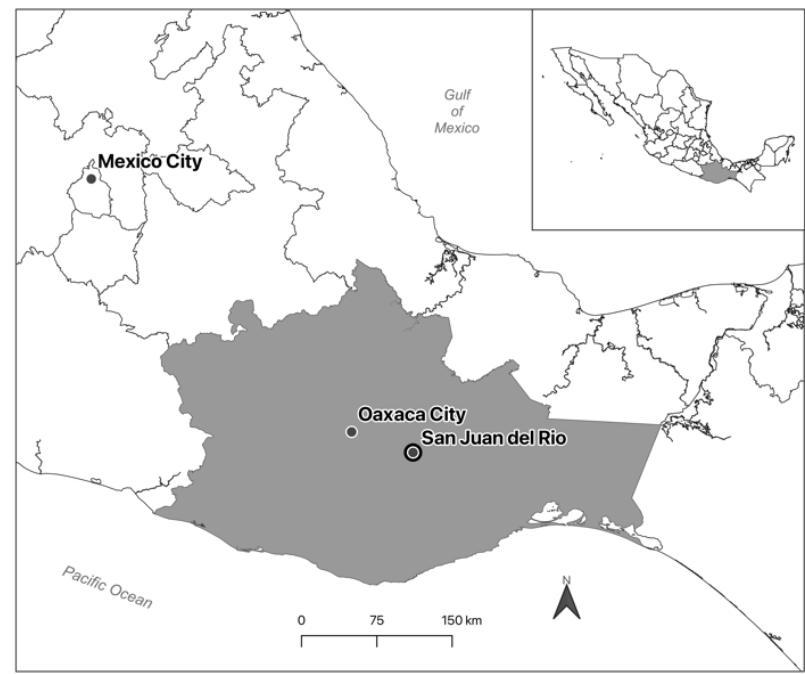

Figure 1. Location of San Juan del Río, Oaxaca (source: INEGI. Marco Geoestadístico. 2017).

The community holds title to its communal territory, officially recognized by the Mexican government. They collectively manage their lands and resources under a traditional governance system called Usos y Costumbres [52]. Under this system, civic and communal governance is the responsibility of a commoners' assembly (Asamblea de Comuneros) made up of adult community members who hold rights to lands within the community. The assembly devises rules regarding territorial use and management, which are captured in a written statute (Estatuto Comunal) and enforced by two community-elected bodies: A Commissioner of Communal Resources (Comisariado de Bienes Comunales) and an Oversight Council (Consejo de Vigilancia). One of the Commissioner's most important tasks is to allocate land rights and resolve conflicts between community members. The Oversight Council monitors compliance of community rules, borders with neighboring communities, and the actions and decisions of the Commissioner. Every three years, the assembly democratically elects a new group of incumbents for these two bodies.

We selected San Juan as a case study community because it met several key criteria. It produces artisanal mezcal and is located within Oaxaca's so-called "mezcal region". It is an Indigenous community operating under a common property governance system, but most agave cultivation and mezcal production are organized at a household or family level. In Oaxaca, San Juan is known as an important mezcal-producing community, with most of its inhabitants directly or indirectly linked to the mezcal sector [74]. At least 25 stills in San Juan are owned by local families, who produce mezcal mainly from agave espadín (A. angustifolia) using methods classified as artisanal by the Mezcal Regulatory Council (Consejo Regulador de Mezcal). This requires the use of an underground oven for the baking process, tahona (a large stone wheel) pulled by a horse for the crushing process, wooden vats for the fermentation process, and cooper stills for distillation (NOM-070-SCFI2016) [75].

\subsection{Methods}

Authorization to conduct this research was obtained from community authorities in San Juan in September 2018, along with research ethics approval granted by the Ethics Board at the University of Manitoba (HS21856 (J2018:036)), Canada. Fieldwork and data collection included participatory interpretation of satellite imagery with community authorities to show the LULC dynamics in the San Juan territory, semi-structured interviews with community members to gather data on the key processes that drove these LULC dynamics, and a document review (focused on the San Juan del Río Community Statute, San Juan del Río Biocultural Protocol, and official norms) to gather information on important past events and regulations linked to the historical development of mezcal in the community. Below we provide further details on the first two data collection methods. 
From October 2018 to April 2019, four LULC interpretation sessions (1.5 to 2 h) were conducted with representatives of San Juan's communal authorities. A total of 5 authority members (males between 45 and 64 years old) participated in session 1, 4 authority members (males between 55 and 64 years old) participated in session 2, 5 authority members (males between 45 and 64 years old) participated in session 3, and 6 authority members (males between 45 and 64 years old) participated in session 4 . The materials used for these sessions were: 1 printed aerial photograph (union of 6 orto photographs 1:20,000) [76] and 3 printed satellite images [77-79] showing San Juan Territory (Table 1) delineated by a boundary polygon [80].

Table 1. Satellite images used and band combinations.

\begin{tabular}{cccc}
\hline Image & Date & Band Combination & Source \\
\hline Landsat 7 & 2001 & $4,3,2$ & USGS \\
Landsat 8 & 2013 & $5,4,3$ & USGS \\
Landsat 8 & 2019 & $5,4,3$ & USGS \\
\hline
\end{tabular}

During the first session, participants defined 4 LULC categories: (1) pine/oak forest; (2) (low) tropical dry forest; (3) agave crops; (4) urban zone. Participants drew polygons on the INEGI Aerial Photograph (1993) and classified them in accordance with the previously mentioned categories. Following the same method, participants interpreted the 2001, 2013, and 2019 Landsat images during the second, third, and fourth sessions, respectively.

Using the participants' classification and own visual interpretation, LULC polygons of the INEGI aerial photograph (1993) were digitized — using the software QGIS 3.16 [81]—to create a LULC map for 1993. Visual interpretations were used to create the training points (file containing sample information about the spectral signatures contained in the image that will allow the classification) that allowed us to conduct a supervised classification using the Semi-Automatic Classification Plugin (SCP) version 7 for QGIS 3.16 [82]. The categories defined by the community representatives were the same categories used for this supervised classification. The accuracy assessment was calculated using the ArcGIS 10.8 [83] software through accuracy points (Compute Confusion Matrix tool-ArcGIS Spatial Analyst) that allowed us to calculate kappa index (kappa index (k) allows one to measure the degree of agreement between two raters who categorize items into classes that are mutually exclusive. The formula used to calculate kappa is $k=\left(p_{o}-p_{e}\right) /\left(1-p_{e}\right)$, where $p_{o}$ is the relative observed agreement between the two raters and $p_{e}$ is the hypothetical probability of change agreement [84]) to contrast to the participants' classifications of satellite imagery (ground truth) to the supervised classification results tool. Kappa ranks from 0 to 1, and it can be interpreted as indicated by Table 2 [84]:

Table 2. Ranking criteria of kappa index.

\begin{tabular}{cc}
\hline Kappa (k) & Level of Agreement \\
\hline$<0.00$ & Poor \\
$0.00-0.20$ & Slight \\
$0.21-0.40$ & Fair \\
$0.41-0.60$ & Moderate \\
$0.61-0.80$ & Substantial \\
$0.81-1.00$ & Almost perfect \\
\hline
\end{tabular}

Errors were corrected based on the participant's LULC interpretation using the SCP Raster Edit tool. LULC change was calculated using SCP's Land Cover Change tool (Figure 2). 


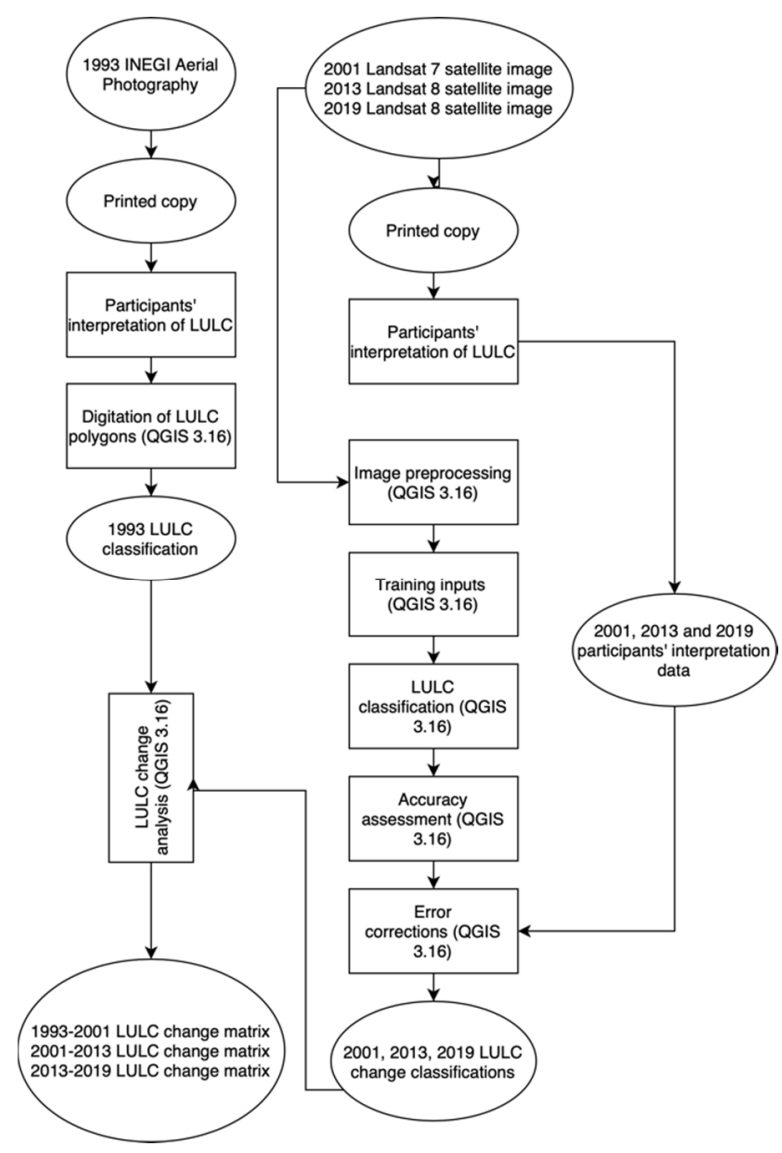

Figure 2. Workflow of LULC analysis.

Using the results of this analysis, LULC maps were created for 4 specific years (1993, $2001,2013,2019)$. The total area of each LULC category was calculated for these 4 classifications, as were change rates $(r)$ using the following Equation (1) [85]:

$$
r=1-1-{\frac{A_{1}-A_{2}}{A_{1}}}^{\frac{1}{t}},
$$

where $A_{1}$ is the total area of one LULC category at a given time $1, A_{2}$ is the total area of the same LULC category at a given time 2, while $t$ is the number of years from time 1 to time 2 . The resulting LULC change rates have a positive or negative sign. Negative sign rates indicate the category area increase while positive signs indicate the category area loss. Transition matrixes showing the surface increase and decrease for each LULC category (total area and percentages) were also created for each period.

Additional to the LULC interpretation sessions described above, semi-structured interviews with community members were conducted over a 7-month period from October 2018 to April 2019. Through a snowball sampling technique, a total of 19 informants were selected: 3 authority representatives (males between 55 and 64 years old), 10 agave and mezcal producers (owners of a still), and 6 agave-only producers. Of the 16 producers interviewed, 14 were male and 2 were female. Ten producers were between 55 and 64 years of age, with six between 25 and 54 years of age. At the time of the research, there were 25 mezcal producers (owners of their own still) in the community, and we estimated a total of 350 to 400 agave growers, each one of them with land plots of at least 2 hectares; authorities did not keep official data on the number of producers, which varies over time in response to agave price swings and fluctuating demand (See Lira et al., 2022 for details). The interviews with authority representatives focused on topics related to community resource use and management rules (for land, wild agaves, water, and firewood) and perceptions about market demand for agave and mezcal and its impact on these and other 
community resources. Interviews with producers focused on agave cultivation and mezcal production dynamics, changes in market demand, rules in use for community resources, and the impacts of rising market demand (for agave and/or mezcal) on those resources. All interviews were audio recorded and transcribed. Data were coded by identifying key topics and the linkages between them [86], using the qualitative data analysis software NVIVO 11 [87].

\section{Results}

\subsection{The Growth of San Juan Del Rio Mezcal Sector over Time}

Figure 3 shows, in chronological order, a series of key events associated with agave and mezcal production in San Juan for the period 1950 to 2017. This draws on both interview and document review data.

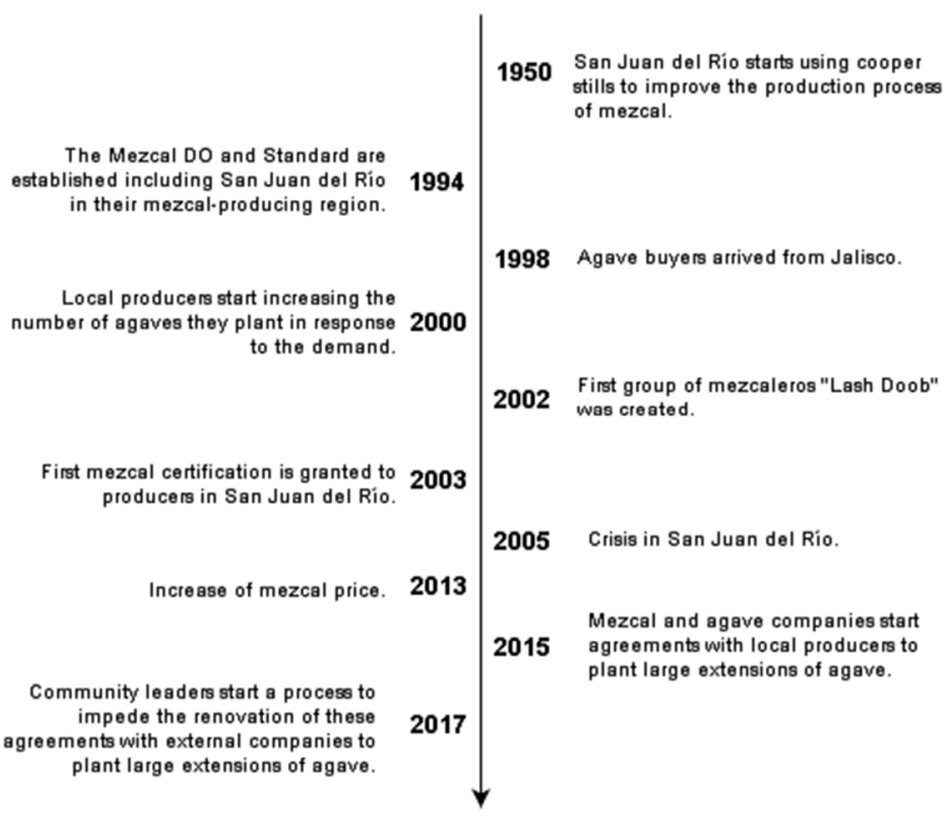

Figure 3. Main events regarding mezcal and agave production in San Juan del Río (Sources: Interview data and San Juan del Río Biocultural Protocol, 2020).

The timeline can be broken into two main periods of specific relevance to this research. First is the period that runs from 1950 to the early 1990s. Before 1950, San Juan used clay pots to distill but then began to adopt copper stills that significantly changed their production process, making it much more efficient [74].

Interview data show that from the 1950s through to the 1990s, mezcal produced in San Juan was largely consumed by locals, with some finding its way to communities in the neighboring Sierra Norte and Mixes regions for purchase or barter:

"People would sell bulk mezcal to neighboring villages in the Mixes or Sierra Norte regions. It was a very good exchange relationship and it sometimes involved bartering; for example, they would give mezcal in exchange for coffee." (Méndez, Israel., 2019. Interview with María Lira. Personal interview. San Juan del Río, Oaxaca, Mexico,

March 10)

During this period, producers might distill 20 to $40 \mathrm{~L}$ of mezcal and travel through these regions (for days at a time) to sell or exchange what they could. This enabled San Juan to build a relationship with other communities and their reputation as producers of quality mezcal. The spirit was still not popular in the large cities of Mexico, let alone internationally, and production remained small-scale.

This all changed in the 1990s when the mezcal DO and standard (NORMA Oficial Mexicana NOM-070-SCFI-1994 [88]) were established, and mezcal gradually became better 
known among people living in large urban centers, as restaurants and bars started to incorporate mezcal into their menus, and the first export brands were established. San Juan was part of the newly coined "mezcal region" of Oaxaca (included in the DO), allowing its producers to obtain their certifications to legally produce and distribute mezcal if they met the stipulations set by the standard. Another important moment came in the late 1990s when buyers from Jalisco-where tequila (another agave-based mezcal) originates—arrived in San Juan, looking to buy large volumes of agave because of a scarcity of agave in their home region. This encouraged farmers in San Juan to plant more agave espadín (A. angustifolia), as well as blue agave (A. tequilana), because of the anticipated demand. However, while these buyers purchased the agave available in San Juan during their initial visits, few returned in the mid-2000s to buy the newly planted agave now matured and ready for harvest. This led to an economic crisis in the community in 2004 and 2005 and the migration of some community members to the USA and Mexican urban centers in search of work [74].

Despite the problems caused by unsold agave, the mezcal sector in San Juan continued to establish itself and develop in new ways. In 2002, San Juan saw its first mezcal producer group "Laajsh Doob" created, and a year later, the first producers in San Juan were certified by the Mexican council that was set up to regulate the quality of Mezcal (COMERCAM, Consejo Mexicano Regulador De La Calidad del Mezcal, now called CRM, Consejo Regulador del Mezcal) [74] (President of the Commissioner of Communal Resources. 2018. Interview with María Lira. Personal interview. San Juan del Río, Oaxaca, Mexico, November 11) (Abad, Karina (Los Danzantes). 2019. Interview with María Lira. Personal interview. San Juan del Río, Oaxaca, México, April 17). San Juan gained further visibility as a mezcal producer. Prices for mezcal climbed, and by the early 2010s, market demand resulted in more local people being involved in agave cultivation, mezcal production, or both.

A key development followed in 2015 when the first agreements were signed between agave growers and external companies to expand agave cultivation. This prompted an institutional response at the community level, as concerns surfaced about the influence of outside entities and the extent of land-use change and resource depletion.

\subsection{LULC Analysis for the Period 1993-2019}

These changes and events provide important context to understand the linkages between global mezcal markets and LULC dynamics in the places and territories where mezcal is produced. As described in the methods section, the accuracy of the supervised classification was calculated through k (Kappa values), and our results (Table 3) (see Supplementary Materials Tables S1-S3) show a substantial level of agreement between the supervised classification and the participants' interpretation of satellite images.

Table 3. Kappa values for the 2001, 2013, and 2019 supervised classifications.

\begin{tabular}{ccc}
\hline LULC Classification Year & k Value & Level of Agreement \\
\hline 2001 & 0.75 & Substantial \\
2013 & 0.80 & Substantial \\
2019 & 0.80 & Substantial \\
\hline
\end{tabular}

In this following section, we present the results of our LULC analysis for the period 1993-2019 (Table 4) (see Supplementary Materials Tables S4-S6), which covers the period when the mezcal sector in San Juan grew and took off as it became integrated into national and international markets.

Figure 4 and Table 5 show the percentages of each LULC category for each year, with Figure 5 showing the extent of these changes via four LULC maps. 
Table 4. LULC transition matrix 1993-2019 (ha).

\begin{tabular}{cccccc}
\hline & Pine/Oak & Tropical Dry Forest & Agave & Urban Zone & Total 1993 \\
\hline Pine/Oak & 1500.12 & 251.1 & 122.04 & 0.99 & 1874.25 \\
Tropical Dry Forest & 19.98 & 3561.84 & 1242.54 & 16.29 & 4840.65 \\
Agave & 33.57 & 191.97 & 177.84 & 0.27 & 403.65 \\
Urban Zone & 0 & 0.18 & 0.63 & 1.98 & 2.79 \\
Total 2019 & 1553.67 & 4005.09 & 1543.05 & 19.53 & 7121.34 \\
\hline
\end{tabular}

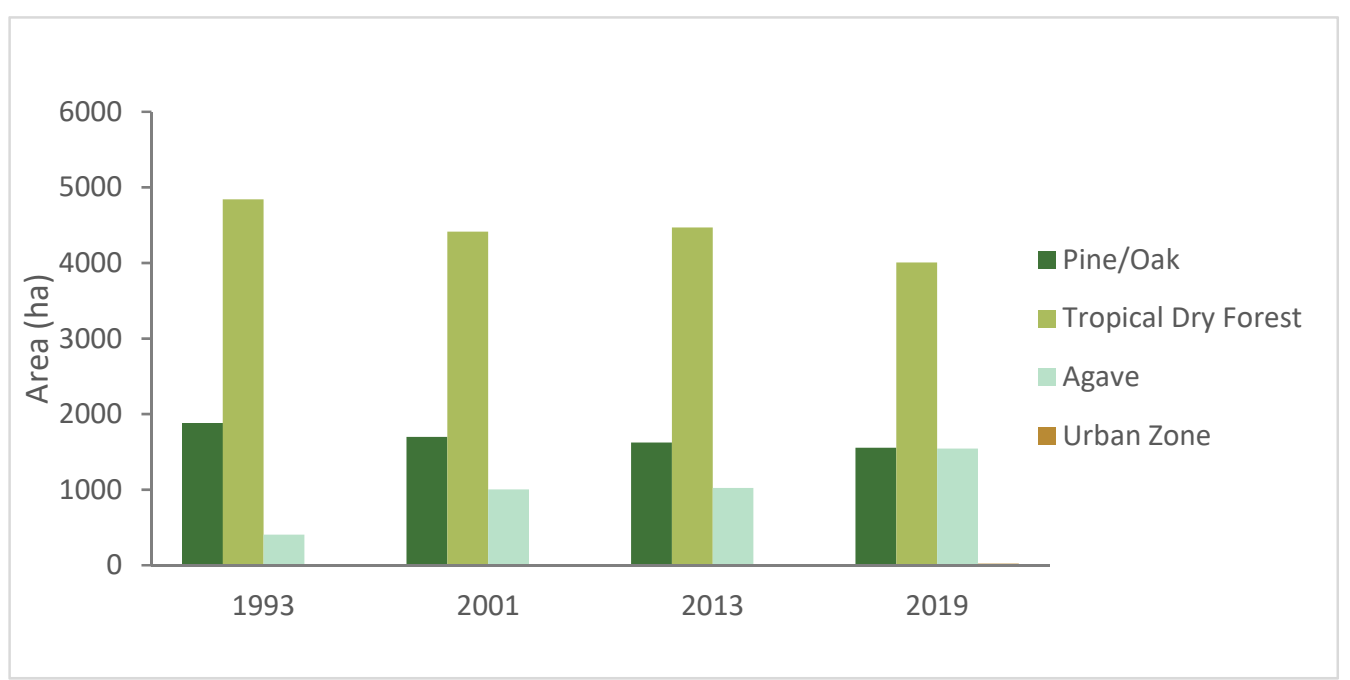

Figure 4. Graph showing the LULC area for each category during the study period.

Table 5. Table showing the percentages of LULC for each year of study.

\begin{tabular}{ccccc}
\hline LULC Category & $\begin{array}{c}\mathbf{1 9 9 3} \\
\mathbf{\%}\end{array}$ & $\begin{array}{c}\mathbf{2 0 0 1} \\
\mathbf{\%}\end{array}$ & $\begin{array}{c}\mathbf{2 0 1 3} \\
\mathbf{\%}\end{array}$ & $\begin{array}{c}\mathbf{2 0 1 9} \\
\mathbf{\%}\end{array}$ \\
\hline Pine/Oak & 26.3 & 23.9 & 22.8 & 21.8 \\
Tropical Dry Forest & 68.0 & 62.0 & 62.8 & 56.2 \\
Agave & 5.7 & 14.1 & 14.4 & 21.7 \\
Urban Zone & 0.0 & 0.1 & 0.1 & 0.3 \\
\hline
\end{tabular}

For the period 1993-2001, our LULC analysis shows an expansion of agave crops leading to a reduction of TDF lands, with TDF lands reduced from $68 \%$ to $62 \%$ coverage of San Juan's territory. Agave expanded from $6 \%$ to $14 \%$ territorial coverage, concentrated in the central and northwest parts of the community's territory.

The areas of agave crops and TDF remained stable for the period 2001-2013. The TDF area saw a slight expansion of $0.3 \%$, while there was a $1 \%$ decrease in pine/oak forest coverage. The period 2001-2013 showed zero change rates for TDF and agave categories (Table 6). Note that a negative sign indicates increase in area while a positive sign denotes a decrease (see methods section for more details).

Table 6. LULC change rates.

\begin{tabular}{ccccc}
\hline LULC Category & 1993-2001 & 2001-2013 & 2013-2019 & Overall (1993-2019) \\
\hline Pine/Oak & 0.01 & 0.00 & 0.01 & 0.01 \\
Tropical Dry Forest & 0.01 & 0.00 & 0.02 & 0.01 \\
Agave & -0.12 & 0.00 & -0.07 & -0.05 \\
Urban Zone & -0.14 & 0.03 & -0.43 & -0.12 \\
\hline
\end{tabular}



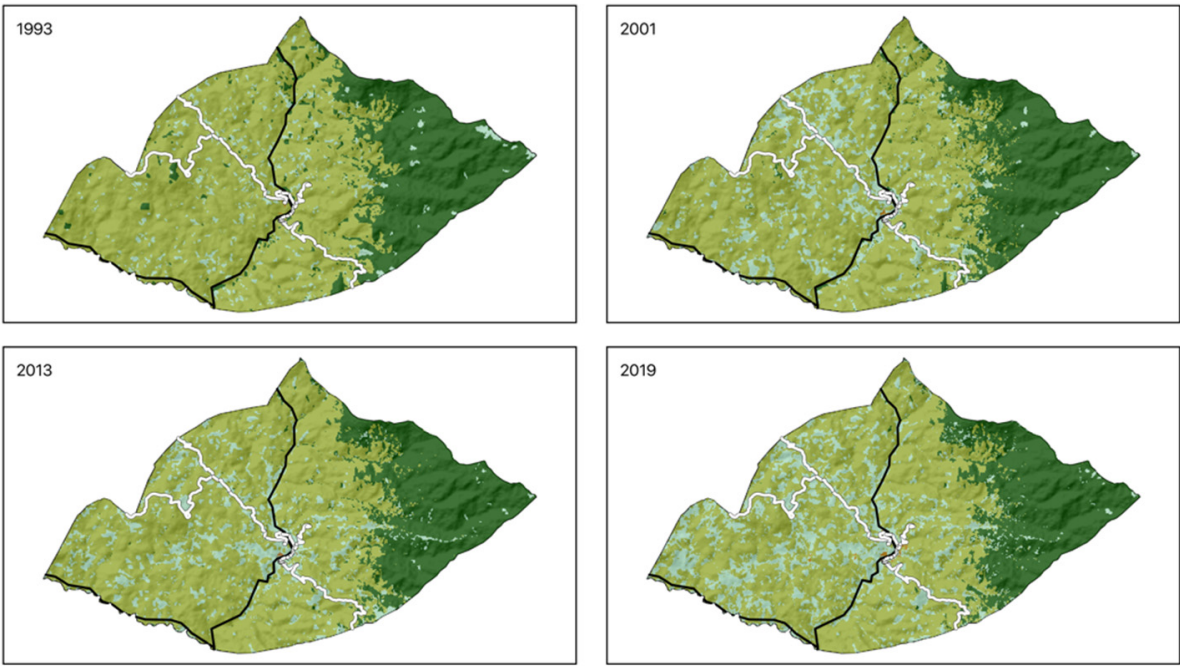

Land Use Land Cover

$\begin{array}{ll} & \text { Pine/Oak } \\ \text { Low Dry Forest } \\ \text { Agave Crops } \\ \text { Urban Zone } \\ \square \text { Roads } \\ \text { - Rivers }\end{array}$

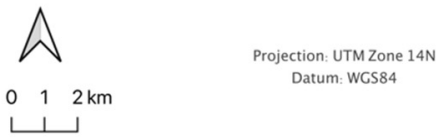

Figure 5. LULC maps San Juan del Río.

Similar to the change observed during the first period of study (1993-2001), the last period in our LULC analysis (2013-2019) shows an expansion in agave cultivation, with territorial coverage increasing from $14 \%$ (1022.6 ha) to $22 \%$ (1543.3 ha) in just 6 years. However, this period shows a lower rate of change $(-0.07)$ than the first period $(-0.12)$. According to community members, the high demand for mezcal and agave, and rising agave prices (according to the Biocultural Protocol of San Juan del Río [74], in 2013, there is a dramatic increase of the agave price from $0.50 \mathrm{MXN} / \mathrm{Kg}$ to $8.00 \mathrm{MXN} / \mathrm{Kg}$ ), were the triggers for community members to invest once more in agave (Martínez, Rogelio., 2019. Interview with María Lira. Personal interview. San Juan del Río, Oaxaca, Mexico, April 13) (Abad, Karina (Los Danzantes), 2019. Interview with María Lira. Personal interview. Santiago Matatlán, Oaxaca, Mexico, April 17) (Martínez, Rodolfo. 2018. Interview with María Lira. Personal interview. Tlacolula, Oaxaca, Mexico, October 8). This resulted in more fields being opened for agave cultivation and more agaves being sold to intermediaries and to local (San Juan) and regional mezcal producers. Furthermore, this period coincided with community mezcal producers beginning to sell more unbottled mezcal to external brands.

\subsection{Community Responses to LULC Change}

It is important to recognize that LULC change has brought about some benefits but also some negative impacts. This has created a source of tension in the community as they consider how they should respond to the LULC they are observing. We explore the tension in this section to highlight the challenges communities face in trying to meet their development goals while doing so in a way that maximizes benefits and minimizes harms.

Interview data suggest that growth in the mezcal sector has improved the quality of life in San Juan and other Zapotec communities in the region, providing employment to community members, as well as for laborers from neighboring communities, such as Tepuxtepec Mixes, who are hired to work in agave fields and local stills. The mezcal producers expressed contentment at being able to work and profit from an activity that is part of their identity and community tradition. Moreover, a revitalized mezcal sector has provided a source of income for young community members, allowing them to stay in the community, and encouraged some migrants to return to San Juan: 
"I was working in Los Angeles for around 20 years. I came back and started planting agave, producing mezcal again. When I returned, I started building the still in this land plot and started producing mezcal again. Now, I want to start my own brand." (Martínez, Rogelio., 2019. Interview with María Lira. Personal interview. San Juan del Río, Oaxaca, Mexico, April 13)

However, the rapid expansion of agave fields funded, in part, by external capital and the limited local benefits that that result, have become a source of concern for community authorities. Given the high prices of agave, external actors have attempted to invest in the production of agave by signing contracts with community members to plant agave at a large scale (Figure 4). This not only put pressure on the community's natural resources but also undermined the customary institutions in place to manage these (and other territorial) resources; it ignored community rules that forbid the use of external capital to work community resources [52].

"Back in the day, we used to plant 500 or 1000 agaves. The rich people would plant 2000 or 3000 and they were still able to weed with a shovel. Now, with this whole mezcal boom, people are going crazy. They start to slash and burn their land plots at a larger scale and then it is not going to be possible to weed them out with the shovel. People fall into the trap of using herbicides to weed their plots. The authorities are worried about this." (President of the Commissioner of Communal Resources., 2018. Interview with María Lira. Personal interview. San Juan del Río, Oaxaca, Mexico, November 11)

During the period 2015-2017, an estimated 10 community members signed contracts with external companies or investors to grow agave on community lands and at a larger scale than had been the norm. When interviewed, community authorities explained that 40,000 agaves were planted in 2017 alone, and contracts were being amended to increase this to 100,000 agaves for 2018 (President of the Commissioner of Communal Resources. 2018. Interview with María Lira. Personal interview. San Juan del Río, Oaxaca, Mexico, November 11). Companies paid for the agave seedlings and the nursery labor required (planting, weeding twice a year, and cultivating the agave), and in some cases, they paid producers a fee for overseeing the work. Following harvest, the company kept $75 \%$ of the agaves produced, with the remainder left to the community member to sell or to distill into mezcal. The community authorities in charge at the time allowed these contracts, failing to enforce the rules contained in the community statute. Community rules dictate that members can work their land plots and profit from them, but they cannot collaborate with people external to the community or bring in external capital. With a new administration in office, the issue became a source of contestation and conflict in the community, requiring much debate within the assembly throughout 2018.

The community responded by instituting improved enforcement of community rules and strengthening their dialogue on the issue [52]. However, given continued demand for mezcal, the authorities remain worried about how ongoing market pressures might impact land use and the natural resource base and whether the community can implement effective institutional responses. Along with the expansion of agave fields, recent years have seen producers adopt new practices that include the planting of agave in vertical rows uphill (which farmers say reduces the need to weed) and increased use of chemical herbicides and pesticides. Anecdotal evidence suggests that this has exacerbated soil erosion and led to a localized decline in grasshoppers (commonly called chapulines), which are an important part of the local diet. In addition, while resource management rules restrict access to and harvesting of pine and oak forest, the clearing of TDF to grow agave is permitted, and community members are allowed to plant as much agave as they can (using their own capital). For most community members, agave expansion is seen as a positive and a path to economic prosperity. Local perceptions on conservation are focused on the community's pine and oak forest; tropical dry forest is considered for its productive (agricultural) potential rather than ecological or biodiversity value. 


\section{Discussion}

By promoting concepts such as telecoupling, land system science is gradually adopting a more interdisciplinary approach that recognizes the complexity of land systems and the different components and interactions that they involve; furthermore, by incorporating a wider range of methods, such as qualitative and mixed-method approaches, it is possible to address social and economic issues around land changes [12]. This research makes use of that integrative approach to combine spatial and qualitative methods to examine the LULC dynamics and its linkages to external markets through the growing demand of mezcal.

Past studies have assessed the sustainability of artisanal production systems from socio-cultural [54,55], economic [55], or ecological perspectives [55,56]; however, there has been limited research addressing the LULC change dynamics linked to these production systems. LULC studies using remote sensing techniques have produced key information on the devastating effects that industrial export crops have caused to landscapes in tropical countries $[17,21,22]$, with recent studies addressing the links between consumption and distant land-use changes through supply chains [11]. LULC dynamics linked to production systems for artisanal products have been overlooked, with sustainable outcomes from such systems assumed rather than empirically proven [89].

Our case focused on LULC dynamics in an Indigenous territory in Oaxaca, Mexico, to show how these dynamics are shaped by growing markets and market demand for mezcal, a traditional spirit branded and sold as an artisanal product. Mezcal has gone through a process of commoditization started by urban elites in the main cities of Mexico and other countries in North America and Europe. Since the late 1990s, producers in San Juan have experienced first-hand the growing interest in the mezcal they produce and the traditional knowledge around craft production techniques that they hold. San Juan producers were among the first in the country to receive nationally recognized mezcal certification; they have experimented with forms of cooperative production within their community and have built relations with some of the most important and well-known brands selling mezcal nationally and abroad.

Such integration into a global value chain has subsequently driven important LULC change dynamics in recent years. Our results show an overall expansion of agave crops from $5.7 \%$ to $21.7 \%$ in 26 years. In the first period of study (1993-2001), our results show an expansion of agave crops area from $6 \%$ to $14 \%$ and a $6 \%$ reduction of the TDF area. This is linked to the arrival of tequila producers from Jalisco looking to purchase high volumes of agave, which motivated local farmers to expand production. The second period of study shows a stable area percentage for agave crops and minor changes for the TDF area. Our interview data show that this was linked to a crisis in the community that resulted from buyers from Jalisco not returning to buy the agave when it was ready to be harvested. The 2013-2019 period of analysis shows a similar dynamic as the first period, an expansion of agave crops from 14 to $22 \%$, but this time because of the emerging markets for of mezcal and the associated growth in demand. Beyond the LULC dynamics, another source of concern is the growing adoption of agricultural practices that can be harmful to soil and local biodiversity, for example, the trend to plant agaves in vertical rows uphill and the use of chemical pesticides and herbicides. The introduction of these practices has resulted from a growing pressure to improve the efficiency of agave production given the high demand from external markets.

Although mezcal has been marketed under an alternative production narrative that promotes sustainability [90], we see how consumption in distant areas has driven LULC changes in local production sites. This work contributes to building evidence that global value chains impact the landscapes, societies, economies, and cultures of rural and indigenous communities [62,89,91], adding to studies already published on artisanal fisheries [92], traditional foods $[54,55,93]$, and artisanal cheese [94]. While such products are often presented as an alternative to industrially produced versions, their production systems and related processes are not immune to negative environmental impacts even when following a logic of production based on small-scale, family-based enterprises [89]. 
This is not to say that producer communities cannot act to negate any such negative impacts. As presented in Lira et al. [52], locally crafted institutions have played a role in mediating the relationship between San Juan del Río mezcal and agave producers-inserted in a commons governance system-and global markets. However, these institutions, which were not originally designed to face the challenges of global markets, still show deficiencies and are going through a process of continuous adaptation to ensure the enforcement of current rules, monitor rule compliance, and encourage dialogue among community members. The presence of commons institutions in San Juan del Río has allowed community members to work and profit from mezcal and agave, consider the sustainability of mezcalbased development given its impacts on natural resources and customary institutions, and maintain a level of autonomy from national and international markets. Nevertheless, several challenges remain with market volatility and possible contrasting scenarios for the future of demand around agave and mezcal. Therefore, community institutions not only need to be adaptable but also require recognition and support from actors in the value chain and the national and global institutions regulating the mezcal industry [95].

Another dimension of LULC change we identified through our research is the conversion of TDF into agave fields. In San Juan, the expansion of agave crops drove an associated loss of TDF. Indeed, the LULC change patterns driven by agave demand for mezcal production show similar patterns to LULC change for a previous period when agave was bought up by tequila producers from Jalisco who operate under an industrial rather than artisanal system. While TDF is considered an important ecosystem in Mexico for biodiversity [66], ecosystem services (erosion prevention, habitat for wildlife, pollination, and temperature regulation) [68], and livelihood [96], it is threatened nationally, with more than $70 \%$ of its area converted to agricultural or urban uses [65]. Institutional and policy discourses, programs, and investments related to TDF in Mexico have largely focused on the potential of these areas for agriculture- or livestock-related activities, and it is likely that this has influenced the TDF-related use and management perceptions of people living in rural areas $[97,98]$. In Mexico, only $0.2 \%$ of TDF is under protection [65]. Among San Juan community members, TDF was not seen as true "monte" or forest, unlike areas of pine-oak forest in the east of the communal territory, and this perception has likely had an impact on efforts to protect or sustainably manage such ecosystems. While San Juan has enacted strict rules around how pine and oak forests are accessed and used by community members, this is not the case for areas of TDF, where land plots are assigned, and forest is cleared for agave production. Although the communal statute regulates hunting and limits external investment on community lands, protecting community autonomy and preventing a more intense expansion of agave crops [52], no rules address LULC change in TDF zones.

Further research is needed to build on limited previous work $[97,98]$ and analyze the degree to which local perceptions shape how TDF-based ecosystems are used, managed, and protected (or not) from land-use change and activities (i.e., agricultural expansion, increased use of chemical pesticides and herbicides). Given growing mezcal markets, San Juan will most likely remain a center of agave and mezcal production in the region. Therefore, TDF will remain vulnerable to future market dynamics and price swings, and so action is required from institutions at multiple levels of government-such as SEMARNAT (Ministry of Environment and Natural Resources) at the federal level and SEDESO (Ministry of Environment, Energy, and Sustainable Development) at the state level-to increase the awareness on the importance of TDF and the best practices to enable sustainable management over time.

\section{Conclusions}

This paper adds to the existing literature on LULC through our focus on the telecoupling of artisanal products, global markets, and the resulting effects on LULC and customary institutions. Despite a narrative that such products offer a sustainable alternative to agro-industrial commodities, our results show how artisanal product value chains can not only drive LULC and modify landscapes but can also stress the territorial gover- 
nance of Indigenous producer communities. Our case study demonstrates how the value and perceptions around certain ecosystems, in this case, tropical dry forest, potentially have an impact on the general concern or implementation of local efforts for their protection and sustainable management. It also highlights the role that commons institutions play to mediate the relationship between local producers and external markets to balance economic development with the sustainable management of community resources. Our results show that telecoupling places stress on customary governance, a process we have described in more detail elsewhere [52]. One of the key points made in that work is that the volatility of markets will require customary commons institutions to adapt to the changing strategies of market actors. A specific gap that was revealed was the lack of attention paid to such customary institutions by DO regulations and associated structures. This has led to the possibility of mezcal production systems that are certified for national and global markets to undermine these institutions and cause social and environmental harms, and points to the need for further research to encourage certification systems to incorporate Indigenous perspectives for artisanal products or even consider new types of certification systems governed by Indigenous producers themselves. Such research should be undertaken in partnership with Indigenous communities, respecting their autonomy and right to selfdetermination, to identify institutional innovations that ensure producer communities receive equitable benefits from the global value chains established to commodify their production knowledge and techniques.

Supplementary Materials: The following supporting information can be downloaded at: https: / / www.mdpi.com/article/10.3390/land11030387/s1, Table S1: Confusion matrix LULC supervised interpretation 2001; Table S2. Confusion matrix LULC supervised interpretation 2013; Table S3: Confusion matrix LULC supervised interpretation 2019; Table S4: LULC transition matrix 1993-2001; Table S5: LULC transition matrix 2001-2013; Table S6: LULC transition matrix 2013-2019.

Author Contributions: Conceptualization, M.G.L., I.J.D.-H. and J.P.R.; Methodology, M.G.L., I.J.D.-H. and J.P.R.; Validation, M.G.L.; Formal Analysis, M.G.L.; Investigation, M.G.L.; Resources, I.J.D.-H.; Data Curation, M.G.L.; Writing-Original Draft Preparation, M.G.L.; Writing-Review and Editing, M.G.L., I.J.D.-H. and J.P.R.; Visualization, M.G.L.; Supervision, I.J.D.-H. and J.P.R.; Project Administration, M.G.L.; Funding Acquisition, I.J.D.-H. and M.G.L. All authors have read and agreed to the published version of the manuscript.

Funding: This research was funded by the Social Sciences and Humanities Research Council (Canada) (grant numbers: 435-2015-1478 and 435-2020-0923) and the National Council of Science and Technology (Conacyt Mexico) (scholarship: 438406).

Institutional Review Board Statement: This research has been approved by the Joint Faculty Review Ethics Board, University of Manitoba HS21856 (J2018:036).

Informed Consent Statement: Informed consent was obtained from all subjects involved in the study.

Data Availability Statement: Publicly available datasets were analyzed in this study. These data can be found here: Instituto Nacional de Estadísticas y Geografía (INEGI) Ortoimágenes (https: / / www.inegi.org.mx/temas/imagenes/ortoimagenes/\#Descargas Accesed: 15 December 2021) and United States Geological Survey, Department of the Interior (http: / / earthexplorer.usgs.gov Accesed: 15 December 2021).

Acknowledgments: We want to thank the community of San Juan del Río for making this research possible. Thanks to Estudios Rurales y Asesoría Campesina, A.C., for their support and guidance during our fieldwork in Oaxaca. We thank anonymous reviewers for their insightful comments and suggestions.

Conflicts of Interest: The authors declare no conflict of interest. 


\section{References}

1. Lambin, E.F.; Geist, H.; Rindfuss, R.R. Introduction: Local Processes with Global Impacts BT-Land-Use and Land-Cover Change: Local Processes and Global Impacts. In Land-Use and Land-Cover Change; Global Change-The IGBP Series; Lambin, E.F., Geist, H., Eds.; Springer: Berlin/Heidelberg, Germany, 2006; pp. 1-8.

2. Turner, B.L.; Lambin, E.F.; Reenberg, A. The Emergence of Land Change Science for Global Environmental Change and Sustainability. Proc. Natl. Acad. Sci. USA 2007, 104, 20666-20671. [CrossRef]

3. Verburg, P.H.; Crossman, N.; Ellis, E.C.; Heinimann, A.; Hostert, P.; Mertz, O.; Nagendra, H.; Sikor, T.; Erb, K.-H.; Golubiewski, N.; et al. Land System Science and Sustainable Development of the Earth System: A Global Land Project Perspective. Anthropocene 2015, 12, 29-41. [CrossRef]

4. Robinson, D.T.; Brown, D.G.; French, N.H.F.; Reed, B.C. Linking Land Use and the Carbon Cycle. In Land Use and the Carbon Cycle: Advances in Integrated Science, Management, and Policy; Reed, B.C., Brown, D.G., Robinson, D.T., French, N.H.F., Eds.; Cambridge University Press: Cambridge, UK, 2013; pp. 3-23.

5. Terzi, F.; Bolen, F. Urban Sprawl Measurement of Istanbul. Eur. Plan. Stud. 2009, 17, 1559-1570. [CrossRef]

6. Hansen, M.C.; DeFries, R.S. Detecting Long-Term Global Forest Change Using Continuous Fields of Tree-Cover Maps from 8-Km Advanced Very High Resolution Radiometer (AVHRR) Data for the Years 1982-99. Ecosystems 2004, 7, 695-716. [CrossRef]

7. Boillat, S.; Scarpa, F.M.; Robson, J.P.; Gasparri, I.; Aide, T.M.; Aguiar, A.P.D.; Anderson, L.O.; Batistella, M.; Fonseca, M.G.; Futemma, C.; et al. Land System Science in Latin America: Challenges and Perspectives. Curr. Opin. Environ. Sustain. 2017, 26-27, 37-46. [CrossRef]

8. Grau, H.R.; Aide, M. Globalization and Land-Use Transitions in Latin America. Ecol. Soc. 2008, 13, 16. Available online: https:/ / www.ecologyandsociety.org/vol13/iss2/art16/ (accessed on 10 August 2021). [CrossRef]

9. Liu, J.; Hull, V.; Batistella, M.; DeFries, R.; Dietz, T.; Fu, F.; Hertel, T.W.; Izaurralde, R.C.; Lambin, E.F.; Li, S.; et al. Framing Sustainability in a Telecoupled World. Ecol. Soc. 2013, 18, 26. [CrossRef]

10. Pendrill, F.; Persson, U.M.; Godar, J.; Kastner, T. Deforestation Displaced: Trade in Forest-Risk Commodities and the Prospects for a Global Forest Transition. Environ. Res. Lett. 2019, 14, 055003. [CrossRef]

11. Green, J.M.H.; Croft, S.A.; Durán, A.P.; Balmford, A.P.; Burgess, N.D.; Fick, S.; Gardner, T.A.; Godar, J.; Suavet, C.; Virah-Sawmy, M.; et al. Linking Global Drivers of Agricultural Trade to On-the-Ground Impacts on Biodiversity. Proc. Natl. Acad. Sci. USA 2019, 116, 23202-23208. [CrossRef] [PubMed]

12. Turner, B.L.; Lambin, E.F.; Verburg, P.H. From Land-Use/Land-Cover to Land System Science: This Article Belongs to Ambio's 50th Anniversary Collection. Theme: Agricultural Land Use. Ambio 2021, 50, 1291-1294. [CrossRef]

13. Eakin, H.; Defries, R.; Kerr, S.; Lambin, E.; Liu, J.; Marcotullio, P.; Messerli, P.; Reenberg, A.; Rueda, X.; Swaffield, S.; et al. Significance of Telecoupling for Exploration of Land-Use Change. In Rethinking Global Land Use in an Urban Era; MIT Press: Cambridge, MA, USA, 2014; pp. 141-162.

14. Sikor, T.; Auld, G.; Bebbington, A.J.; Benjaminsen, T.A.; Gentry, B.S.; Hunsberger, C.; Izac, A.-M.; Margulis, M.E.; Plieninger, T.; Schroeder, H.; et al. Global Land Governance: From Territory to Flow? Curr. Opin. Environ. Sustain. 2013, 5, 522-527. [CrossRef]

15. Gasparri, N.I.; de Waroux, Y.L.P. The Coupling of South American Soybean and Cattle Production Frontiers: New Challenges for Conservation Policy and Land Change Science. Conserv. Lett. 2015, 8, 290-298. [CrossRef]

16. DeFries, R.S.; Rudel, T.; Uriarte, M.; Hansen, M. Deforestation Driven by Urban Population Growth and Agricultural Trade in the Twenty-First Century. Nat. Geosci. 2010, 3, 178-181. [CrossRef]

17. Morton, D.C.; DeFries, R.S.; Shimabukuro, Y.E.; Anderson, L.O.; Arai, E.; del Bon Espirito-Santo, F.; Freitas, R.; Morisette, J. Cropland Expansion Changes Deforestation Dynamics in the Southern Brazilian Amazon. Proc. Natl. Acad. Sci. USA 2006, 103, 14637-14641. [CrossRef]

18. Laurance, W.F. Switch to Corn Promotes Amazon Deforestation. Science 2007, 318, 1721. [CrossRef]

19. Barona, E.; Ramankutty, N.; Hyman, G.; Coomes, O.T. The Role of Pasture and Soybean in Deforestation of the Brazilian Amazon. Environ. Res. Lett. 2010, 5, 024002. [CrossRef]

20. Pendrill, F.; Persson, U.M.; Godar, J.; Kastner, T.; Moran, D.; Schmidt, S.; Wood, R. Agricultural and Forestry Trade Drives Large Share of Tropical Deforestation Emissions. Glob. Environ. Chang. 2019, 56, 1-10. [CrossRef]

21. Hansen, M.C.; Stehman, S.V.; Potapov, P.V.; Arunarwati, B.; Stolle, F.; Pittman, K. Quantifying Changes in the Rates of Forest Clearing in Indonesia from 1990 to 2005 Using Remotely Sensed Data Sets. Environ. Res. Lett. 2009, 4, 034001. [CrossRef]

22. Persson, U.M.; Henders, S.; Cederberg, C. A Method for Calculating a Land-Use Change Carbon Footprint (LUC-CFP) for Agricultural Commodities-Applications to Brazilian Beef and Soy, Indonesian Palm Oil. Glob. Chang. Biol. 2014, 20, 3482-3491. [CrossRef]

23. Browder, J.O.; Pedlowski, M.A.; Walker, R.; Wynne, R.H.; Summers, P.M.; Abad, A.; Becerra-Cordoba, N.; Mil-Homens, J. Revisiting Theories of Frontier Expansion in the Brazilian Amazon: A Survey of the Colonist Farming Population in Rondônia's Post-Frontier, 1992-2002. World Dev. 2008, 36, 1469-1492. [CrossRef]

24. le Polain de Waroux, Y.; Garrett, R.D.; Heilmayr, R.; Lambin, E.F. Land-Use Policies and Corporate Investments in Agriculture in the Gran Chaco and Chiquitano. Proc. Natl. Acad. Sci. USA 2016, 113, 4021. [CrossRef] [PubMed] 
25. Gasparri, N.I. The Transformation of Land-Use Competition in the Argentinean Dry Chaco Between 1975 and 2015. In Land Use Competition: Ecological, Economic and Social Perspectives; Human-Environment Interactions; Niewöhner, J., Bruns, A., Hostert, P., Krueger, T., Nielsen, J.Ø., Haberl, H., Lauk, C., Lutz, J., Müller, D., Eds.; Springer International Publishing: Cham, Switzerland, 2016; pp. 59-73.

26. Meyfroidt, P.; Roy Chowdhury, R.; de Bremond, A.; Ellis, E.C.; Erb, K.H.; Filatova, T.; Garrett, R.D.; Grove, J.M.; Heinimann, A.; Kuemmerle, T.; et al. Middle-Range Theories of Land System Change. Glob. Environ. Chang. 2018, 53, 52-67. [CrossRef]

27. Carmenta, R.; Coomes, D.A.; DeClerck, F.A.J.; Hart, A.K.; Harvey, C.A.; Milder, J.; Reed, J.; Vira, B.; Estrada-Carmona, N. Characterizing and Evaluating Integrated Landscape Initiatives. One Earth 2020, 2, 174-187. [CrossRef]

28. Kupiec, B.; Revell, B. Speciality and Artisanal Cheeses Today: The Product and the Consumer. Br. Food J. 1998, 100, 236-243. [CrossRef]

29. Bessiere, J. Local Development and Heritage: Traditional Food and Cuisine as Tourist Attractions in Rural Areas. Sociol. Rural 1998, 38, 21-34. [CrossRef]

30. Amilien, V. Is Grandmother's Cuisine Traditional Food? A Concept Definition in Tourism Research. In Proceedings of the 8th Nordic Symposium on Hospitality and Tourism Research, Alta, Norway, 18-21 November 1999; pp. 18-21.

31. Tregear, A.; Kuznesof, S.; Moxey, A. Policy Initiatives for Regional Foods: Some Insights from Consumer Research. Food Policy 1998, 23, 383-394. [CrossRef]

32. Ilbery, B.; Kneafsey, M. Producer Constructions of Quality in Regional Specialty Food Production: A Case Study from South West England. J. Rural Stud. 2000, 16, 217-230. [CrossRef]

33. Ilbery, B.; Kneafsey, M. Registering Regional Speciality Food and Drink Products in the United Kingdom: The Case of PDOs and PGIs. Area 2000, 32, 317-325. [CrossRef]

34. Murdoch, J.; Marsden, T.; Banks, J. Quality, Nature, and Embeddedness: Some Theoretical Considerations in the Context of the Food Sector. Econ. Geogr. 2000, 76, 107-125. [CrossRef]

35. Verhaegen, I.; Van Huylenbroeck, G. Costs and Benefits for Farmers Participating in Innovative Marketing Channels for Quality Food Products. J. Rural Stud. 2001, 17, 443-456. [CrossRef]

36. Arfini, F.; Mora, C. Typical and Traditional Products: Rural Effect and Agro-Industrial Problems. In Proceedings of the 52nd Seminar of the European Association of Agricultural Economists, Parma, Italy, 19-21 June 1998.

37. Wiskerke, J.S.C. On Places Lost and Places Regained: Reflections on the Alternative Food Geography and Sustainable Regional Development. Int. Plan. Stud. 2009, 14, 369-387. [CrossRef]

38. Berard, L.; Marchenay, P. Lieux, Temps, et Preuves: La Construction Sociale Des Produts de Terroir. Terrain 1995, 24, 153-164. [CrossRef]

39. Bell, D.; Valentine, G. Consuming Geographies: We Are Where We Eat; Routledge: London, UK, 1997.

40. Montanari, A.; Staniscia, B. Culinary Tourism as a Tool for Regional Re-Equilibrium. Eur. Plan. Stud. 2009, 17, 1463-1483. [CrossRef]

41. Paloviita, A. Consumers' Sustainability Perceptions of the Supply Chain of Locally Produced Food. Sustainability 2010, 2, 1492-1509. [CrossRef]

42. Terrio, S.J. Crafting Grand Cra Chocolates in Contemporary France. Am. Anthropol. 1996, 98, 67-79. [CrossRef]

43. Nygard, B.; Storstad, O. De-Globalization of Food Markets? Consumer Perceptions of Safe Food: The Case of Norway. Sociol. Rural 1998, 38, 35-53. [CrossRef]

44. Tregear, A.; Arfini, F.; Belletti, G.; Marescotti, A. Regional Foods and Rural Development: The Role of Product Qualification. J. Rural Stud. 2007, 23, 12-22. [CrossRef]

45. Vasta, A.; Figueiredo, E.; Valente, S.; Vihinen, H.; Nieto-Romero, M. Place-Based Policies for Sustainability and Rural Development: The Case of a Portuguese Village "Spun" in Traditional Linen. Soc. Sci. 2019, 8, 289. [CrossRef]

46. Dwyer, C.; Jackson, P. Commodifying Difference: Selling EASTern Fashion. Environ. Plan. D Soc. Space 2003, 21, 269-291. [CrossRef]

47. Gatrell, J.; Reid, N.; Steiger, T.L. Branding Spaces: Place, Region, Sustainability and the American Craft Beer Industry. Appl. Geogr. 2018, 90, 360-370. [CrossRef]

48. Jodha, N.S. Market Forces and Erosion of Common Property Resources. In Proceedings of the Agricultural Markets in the Semi-Arid Tropics, Patancheruvu, India, 24-28 October 1985; pp. 227-263.

49. Bollier, D.; Helfrich, S. The Wealth of the Commons: A World Beyond Market. and State; Levellers Press: Amherst, MA, USA, 2014.

50. Ostrom, E. Governing the Commons; Cambridge University Press: Cambridge, UK, 1990.

51. Colchester, M. Sustaining the Forests: The Community-based Approach in South and South-East Asia. Dev. Chang. 1994, 25, 69-100. [CrossRef]

52. Lira, M.G.; Robson, J.P.; Klooster, D.J. Commons, Global Markets and Small-Scale Family Enterprises: The Case of Mezcal Production in Oaxaca, Mexico. Agric. Hum. Values 2022. [CrossRef]

53. Dwyer, L. Saluting While the Ship Sinks: The Necessity for Tourism Paradigm Change. J. Sustain. Tour. 2018, 26, 29-48. [CrossRef]

54. Moscatelli, S.; Gamboni, M.; Dernini, S.; Capone, R.; Bilali, H.E.; Bottalico, F.; Debs, P.; Cardone, G. Exploring the Socio-Cultural Sustainability of Traditional and Typical Agro-Food Products: Case Study of Apulia Region, South-Eastern Italy. J. Food Nutr. Res. 2017, 5, 6-14. [CrossRef]

55. Capone, R.; El Bilali, H.; Bottalico, F. Assessing the Sustainability of Typical Agro-Food Products: Insights from Apulia Region, Italy. New Medit 2016, 15, 28-35.

56. Bilali, H.E.; Calabrese, G.; Iannetta, M.; Stefanova, M.; Paoletti, F.; Ladisa, G.; Bottalico, F.; Capone, R. Environmental Sustainability of Typical Agro-Food Products: A Scientifically Sound and User Friendly Approach. New Medit 2020, 19, 69-83. [CrossRef] 
57. Bowen, S.; Zapata, A.V. Geographical Indications, Terroir, and Socioeconomic and Ecological Sustainability: The Case of Tequila. J. Rural Stud. 2009, 25, 108-119. [CrossRef]

58. Consejo Regulador del Mezcal (CRM). Informe Estadístico; Consejo Regulador del Mezcal: Oaxaca, Mexico, 2020.

59. DOF/IMPI. Resolución Mediante La Cual Se Otorga La Protección Prevista a La Denominación de Origen Mezcal, Para Ser Aplicada a La Bebida Alcohólica Del Mismo Nombre; DOF/IMPI: Mexico City, Mexico, 1994.

60. Vega Vera, N.V.; Pérez Akaki, P.P. Oaxaca y Sus Regiones Productoras de Mezcal: Un Análisis Desde Cadenas Globales de Valor. Perspect. Rural. Nueva Época 2017, 15, 103-132.

61. Palma, F.; Pérez, P.; Meza, Y.V. Diagnóstico de La Cadena de Valor Mezcal En Las Regiones de Oaxaca; COPLADE: Oaxaca, Mexico, 2016.

62. Bowen, S. Divided Spirits: Tequila, Mezcal and the Politics of Production; University of California Press: Oakland, CA, USA, 2015.

63. Gallardo-Cruz, J.A.; Meave, J.A.; Pérez-García, E.A. Estructura, Composición y Diversidad de La Selva Baja Caducifolia Del Cerro Verde, Nizanda (Oaxaca), México. Bot. Sci. 2017, 76, 19-35. [CrossRef]

64. Miles, L.; Newton, A.C.; DeFries, R.S.; Ravilious, C.; May, I.; Blyth, S.; Kapos, V.; Gordon, J.E. A Global Overview of the Conservation Status of Tropical Dry Forests. Proc. J. Biogeogr. 2006, 33, 491-505. [CrossRef]

65. Portillo-Quintero, C.A.; Sánchez-Azofeifa, G.A. Extent and Conservation of Tropical Dry Forests in the Americas. Biol. Conserv. 2010, 143, 144-155. [CrossRef]

66. Ceballos, G.; García, A. Conserving Neotropical Biodiversity: The Role of Dry Forests in Western Mexico. Conserv. Biol. 1995, 9 , 1349-1356. [CrossRef]

67. Dirzo, R.; Ceballos, G. Las Selvas Secas de México: Un Reservorio de Biodiversidad y Laboratorio Viviente. In Diversidad, Amenazas y Áreas Prioritarias Para la Conservación de Las Selvas Secas del Pacífico de México; FCE/CONABIO: Mexico City, Mexico, 2010; pp. 13-17.

68. Maass, J.M.; Balvanera, P.; Castillo, A.; Daily, G.C.; Mooney, H.A.; Ehrlich, P.; Quesada, M.; Miranda, A.; Jaramillo, V.J.; GarcíaOliva, F.; et al. Ecosystem Services of Tropical Dry Forests: Insights from Long-Term Ecological and Social Research on the Pacific Coast of Mexico. Ecol. Soc. 2005, 10, 17. [CrossRef]

69. Janzen, D.H. Tropical Dry Forests: The Most Endangered Major Tropical Ecosystem. In Biodiversity; National Academy Press, 1988; pp. 130-137. Available online: https:/ / www.ncbi.nlm.nih.gov/books/NBK219281/ (accessed on 20 February 2022).

70. Noojipady, P.; Morton, C.D.; Macedo, N.M.; Victoria, C.D.; Huang, C.; Gibbs, K.H.; Bolfe, L.E. Forest Carbon Emissions from Cropland Expansion in the Brazilian Cerrado Biome. Environ. Res. Lett. 2017, 12, 025004. [CrossRef]

71. González-M, R.; García, H.; Isaacs, P.; Cuadros, H.; López-Camacho, R.; Rodríguez, N.; Pérez, K.; Mijares, F.; Castaño-Naranjo, A.; Jurado, R.; et al. Disentangling the Environmental Heterogeneity, Floristic Distinctiveness and Current Threats of Tropical Dry Forests in Colombia. Environ. Res. Lett. 2018, 13, 045007. [CrossRef]

72. Instituto Nacional de Estadísticas y Geografía (INEGI). Censo de Poblacion y Vivienda. 2020. Available online: https://www. inegi.org.mx/programas / ccpv/2020/ (accessed on 11 January 2022).

73. Instituto Nacional de Estadísticas y Geografía (INEGI). Conjunto de Datos Vectoriales de La Carta de Uso Del Suelo y Vegetación. Escala 1:250 000. Serie, V. Conjunto Nacional. 2013. Available online: https://www.inegi.org.mx/app/biblioteca/ficha.html? upc $=702825007024$ (accessed on 15 December 2021).

74. Comunidad Indígena de San Juan del Río; Hernández Márquez, G.Y. Protocolo Comunitiario Biocultural de La Comunidad Agraria y Municipio de San Juan del Río, Oaxaca, Mexico. GEF-PNUD-GYHM 2020. Available online: https: / / absch.cbd.int/database/CPP / ABSCH-CPP-SCBD-253752?fbclid=IwAR3LDdXi-Sv0MC89fyfzbNX9tcFHl4nQ2 vPIsHXOV0eZF3DmHXZZqWQitus (accessed on 3 December 2021).

75. NORMA Oficial Mexicana NOM-070-SCFI-2016. Bebidas Alcohólicas-Mezcal-Especificaciones. 2016. Available online: http: //www.dof.gob.mx/normasOficiales/6437/seeco11_C/seeco11_C.html (accessed on 15 December 2021).

76. Instituto Nacional de Estadísticas y Geografía (INEGI). Ortoimágenes (E14d59a, E14d59b, E14d59c, E14d59d, E14d59e, E14d59f). 1993. Available online: https://www.inegi.org.mx/temas/imagenes/ortoimagenes/\#Descargas (accessed on 13 June 2021).

77. United States Geological Survey, Department of the Interior Landsat-7 Image. Scene ID: LE70240482001101EDC00. USGS Explorer. 2001. Available online: https://landsatlook.usgs.gov/bundle/LE07_L2SP_024048_20010411_20200917_02_T1 .tar?requestSignature=eyJjb250YWN0SWQiOjI2MzMwMTg0LCJkb3dubG9hZElkIjoxMzc1NzExNTYsImRhdGVHZW5lcmF0 ZWQiOiIyMDIyLTAzLTAzVDE3OjI5OjE1LTA2OjAwIiwic2lnbmF0dXJlijoiJDUkJGIyU0ZcL0dyTnlKVzh2dmtsN1VVQ3Q3 ZXBDLkt4Qkc1VnFTb1plcXlCeTI5In0= (accessed on 15 November 2021).

78. United States Geological Survey, Department of the Interior Landsat-8 Image. Scene ID: LC80240482013078LGN02. USGS Explorer. 2013. Available online: https://landsatlook.usgs.gov/bundle/LC08_L1TP_024048_20130319_20200913_02_T1 .tar?requestSignature=eyJjb250YWN0SWQiOjI2MzMwMTg0LCJkb3dubG9hZElkIjoxMzc1Nzc2NzksImRhdGVHZW5lcmF0 ZWQiOiIyMDIyLTAzLTAzVDE3OjM5OjUzLTA2OjAwIiwic2lnbmF0dXJ1IjoiJDUkJDJUUkJ5clltMFNFcFJVRDdqN1NJT2 dJTnRDM2V5OHUw Ym9DSlhOUzdld0IifQ== (accessed on 15 November 2021).

79. United States Geological Survey, Department of the Interior Landsat-8 Image. Scene ID: LC80240482019047LGN00. USGS Explorer. 2019. Available online: https://landsatlook.usgs.gov/bundle/LC08_L1TP_024048_20190216_20200829_02_ T1.tar?requestSignature=eyJjb250YWN0SWQiOjI2MzMwMTg0LCJkb3dubG9hZElkIjoxMzc1Nzg4NTgsImRhdGVHZW5 lcmF0ZWQiOilyMDIyLTAzLTAzVDE3OjQ0OjUyLTA2OjAwIiwic2lnbmF0dXJlijoiJDUkJGkydWczTG5pNUh6bEVHTW5 1TXVrRUxHWEtcL25uUmswVmpSNTZlb0w3U0I0In0= (accessed on 15 November 2021). 
80. Instituto Nacional de Estadísticas y Geografía (INEGI). Marco Geoestadístico. 2017. Available online: https:/ /www.inegi.org. $\mathrm{mx} / \mathrm{app} /$ biblioteca / ficha.html?upc=889463171829 (accessed on 14 November 2021).

81. QGIS.org. QGIS Geographic Information System. Available online: http:/ / www.qgis.org (accessed on 24 November 2021).

82. Congedo, L. Semi-Automatic Classification Plugin: A Python Tool for the Download and Processing of Remote Sensing Images in QGIS. J. Open Source Softw. 2021, 6, 3172. [CrossRef]

83. Environmental Systems Research Institute. ArcGIS Version 10.8; ESRI: Redlands, CA, USA, 2020.

84. Cohen, J. A Coefficient of Agreement for Nominal Scales. Educ. Psychol. Meas. 1960, 20, 37-46. [CrossRef]

85. FAO. Forest Resources Assessment 1990; FAO Forestry Paper; FAO: Rome, Italy, 1996.

86. Bernard, H.R. Research Methods in Anthropology: Qualitative and Quantitative Approaches; Rowman \& Littlefield: Lanham, ML, USA, 2017.

87. QSR International. NVivo Data Analysis Software. 1999. Available online: https://qsrinternational.com/nvivo/nvivo-products/ (accessed on 23 August 2020).

88. NORMA Oficial Mexicana NOM-070-SCFI-1994. Bebidas Alcohólicas-Mezcal-Especificaciones; DOF: Mexico City, Mexico, 2014.

89. Tetreault, D.; McCulligh, C.; Lucio, C. Distilling Agro-Extractivism: Agave and Tequila Production in Mexico. J. Agrar. Chang. 2021, 21, 219-241. [CrossRef]

90. Lira, M.G.; Klooster, D.J.; Peyton, J. The Construction of Value around Mezcal and Its Impact on Indigenous Producer Communities in San Juan del Río, Oaxaca. Unpublished manuscript. n.d.

91. Hernández, J. Paisajes Vemos, de Su Creación No Sabemos. El Paisaje Agavero Patrimonio Cultural de La Humanidad. Relaciones 2013, 136, 115-144. [CrossRef]

92. Kulmiye, A.J. Assessment of the Status of the Artisanal Fisheries in Puntland through Value-Chain Analysis. 2010. Available online: http:/ / shuraako.org/sites / default / files / documents / Assessment $\% 20$ of $\% 20$ the $\% 20$ Status $\% 20$ of $\% 20$ the $\% 20$ Artisanal $\%$ 20Fisheries\%20in\%20Puntland\%20Through\%20Value\%20Chain\%20Analysis.pdf (accessed on 21 October 2021).

93. Gralton, A.; Vanclay, F. Artisanality and Culture in Innovative Regional Agri-Food Development: Lessons from the Tasmanian Artisanal Food Industry. Int. J. Foresight Innov. Policy 2009, 5, 193-204. [CrossRef]

94. Ghadge, A.; Er Kara, M.; Mogale, D.G.; Choudhary, S.; Dani, S. Sustainability Implementation Challenges in Food Supply Chains: A Case of UK Artisan Cheese Producers. Prod. Plan. Control 2021, 32, 1191-1206. [CrossRef]

95. Berkes, F. Community-Based Conservation in a Globalized World. Proc. Natl. Acad. Sci. USA 2007, 104, 15188-15193. [CrossRef]

96. Maass, J.M. Conversion of Tropical Dry Forest to Pasture and Agriculture. In Seasonally Dry Tropical Forests; Cambridge University Press: Cambridge, UK, 1995; pp. 399-422.

97. Castillo, A.; Magaña, A.; Pujadas, A.; Martínez, L.; Godínez, C. Understanding the Interaction of Rural People with Ecosystems: A Case Study in a Tropical Dry Forest of Mexico. Ecosystems 2005, 8, 630-643. [CrossRef]

98. Tarrasón, D.; Urrutia, J.T.; Ravera, F.; Herrera, E.; Andrés, P.; Espelta, J.M. Conservation Status of Tropical Dry Forest Remnants in Nicaragua: Do Ecological Indicators and Social Perception Tally? Biodivers Conserv. 2010, 19, 813-827. [CrossRef] 